\title{
Fuel Options from Microalgae with Representative Chemical Composittons
}

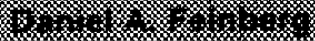
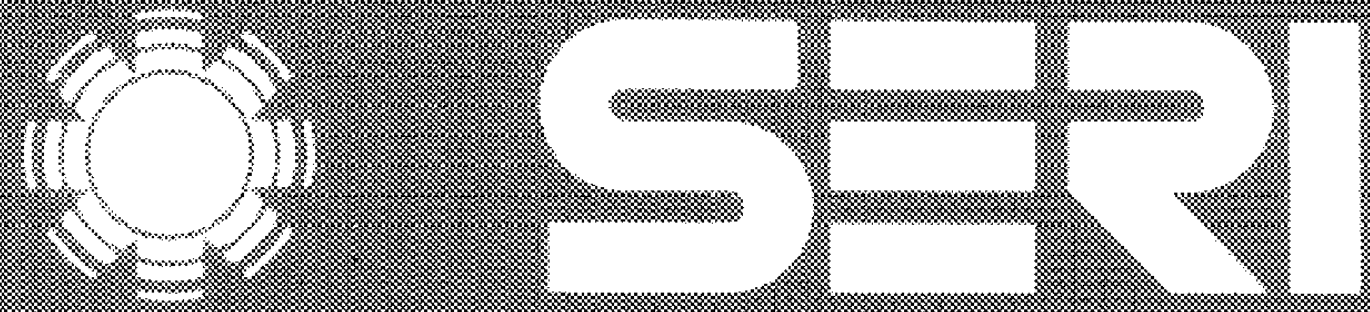

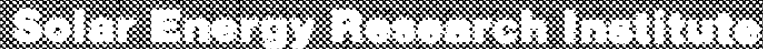

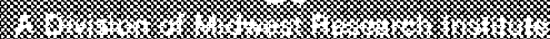

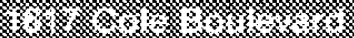

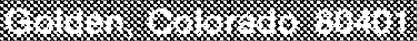

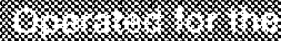

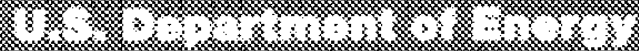

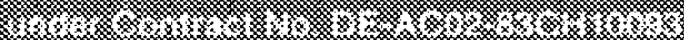


Printed in the United States of America

Available from:

National Technical Information Service

U.S. Department of Commerce

5285 Port Royal Road

Springfield, VA 22161

Price:

Microfiche A01

Printed Copy $\mathrm{A03}$

\section{NOTICE}

This report was prepared as an account of work sponsored by the United States Government. Neither the United States nor the United States Department of Energy, nor any of their employees, nor any of their contractors, subcontractors, or their employees, makes any warranty, express or implied, or assumes any legal liability or responsibility for the accuracy, completeness or usefulness of any information, apparatus, product or process disclosed, or represents that its use would not infringe privately owned rights. 


\title{
Fuel Options from Microalgae with Representative Chemical Compositions
}

\author{
Daniel A. Feinberg
}

July 1984

Prepared under Task No. $\mathbf{4 6 2 5 . 2 0}$

FTP No. 388

Solar Energy Research Institute

A Division of Midwest Research Institute

1617 Cole Boulevard

Golden, Colorado 80401

Prepared for the U.S. Department of Energy Contract No. DE-AC02-83CH10093 
SEP

TR-2427

PREFACE

The Solar Fuels Research Division of the Solar Energy Research Institute, under the Aquatic Species Program, is carrying out a broad range of research activities to develop microalgae as a potential source of renewable liquid fuels. This study examines a variety of microalgal species with representative chemical compositions, ranking each for its potential as a renewable source of ethanol, methane, and lipid-derived fuels such as synthetic diesel fuel (methyl ester). This assessment is based solely on chemical composition and does not take into account the yield factor. The work was performed as a follow-up to "Fuel from Microalgae Lipid Products," by D. Feinberg and A. Hill, which was published in April 1984 as SERI/TP-231-2348.

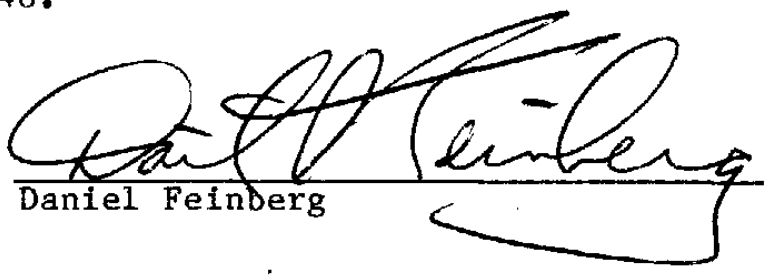

Approved for

SOLAR ENERGY RESEARCH INSTITUTE

Stotsereme

S. H. Browne, Group Manager

Technical Evaluation and Planning Group

Stanley Resale

S. Bull, Division Director

Solar Fuels Research Division

iii 


\section{SUMMARY}

\section{Objective}

To examine various species of microalgae with representative chemical compositions and to evaluate a variety of renewable liquid (and gaseous) fuel options.

\section{Discussion}

Each of the three biochemical fractions of microalgae (1ipids, carbohydrates, and proteins) can be converted into fuels. Lipids have the highest energy content of the three. The lipids of some species are hydrocarbons, similar to those found in petroleum, while those of other species resemble seed oils, which can be converted to a synthetic diesel fuel (ester fue1) by the process known as transesterification. Carbohydratees are commonly converted to ethanol by fermentation. Alternatively, all three fractions can be converted to methane gas by anaerobic digestion. A total of eleven different cases (nine different species) are examined in this report, including four species identified as high-lipid producers, three high-carbohydrate producers, three high-protein producers, and one high-glycerol producer.

Based on the chemical compositions reported for the various species, an estimate is first made of the gross energy content avallable from a unit mass of each species. Then, options are considered that convert each fraction into the desired products. For example, the entire mass might be converted to methane, the carbohydrate fermented to ethanol, the 1ipid converted to ester fuel, or any combintaion of these.

\section{Conclusions}

Among the high-lipid producing species, Botryococcus braunii is unique in that it can produce hydrocarbons at $40 \%$ or higher of its total 11pids. Most of these hydrocarbons are benzene-extractable, aromatic-type compounds, which might be directly usable as liquid fuel. A critical research question is whether sufficiently high growth rates could be achieved to permit econom ically competitive fuel production from this organism. Another high-lipid producer, Nannochloropsis salina, has shown the ability to produce up to $34 \%$ of its total lipid as fatty acids, which can in turn be esterifled to produce ester fuel. Calculations indicate that $53.1 \%$ of the total energy content of this organism can be converted into liquid fuel. It is clear from a chemical composition standpoint that lipid producers offer the most potential for renewable production of high-energy liquid fuel.

Al1 three of the high-carbohydrate producing species examined offer potential as renewable sources of ethano1. The diatom Cyclotella cryptica, with a reported $67 \%$ carbohydrate content, and Chlamydomonas sp., with $59 \%$ carbohydrates, would produce exclusively ethanol, converting approximately $30 \%$ of their total energy contents into a single liquid fuel. Dunaliella salina, on the other hand, contains approximately $3 \%$ fatty acid and $1 \%$ hydrocarbon as 
well as $55.5 \%$ carbohydrate; up to $47 \%$ of its total energy can therefore be converted to liquid fuels.

Although liquid fuels, especially hydrocarbons, are more valuable due to their ease of storage and handling (especially for the vast transportation fuel markets), all the species examined offer great potential as sources for the production of methane via anaerobic digestion. Due to the inherently lower energy requirements and higher conversions for this process, energy utilization efficiencies range from about 68\% (for high-protein producers) to $75 \%$ (for high-1ipid producers). The high-protein producing species, as well as another strain of $\mathrm{D}$. salina that produces about $28 \%$ glycerol, might have an economic advantage due to their coproduction of higher valued products. Detailed examinations of algal productivity data, as well as economic studies, are not required to further quantify the potential of these organisms as renewable fuel producers. 
TABLE OF CONTENTS

$\underline{\text { Page }}$

1.0 Introduction........................................ 1

2.0 Approach......................................... 3

3.0 Fuel Options as Determined by Chemical Composition............. 6

3.1 Botryococcus braunii.............................. 6

3.2 Ankistrodesmus falcatus........................... 8

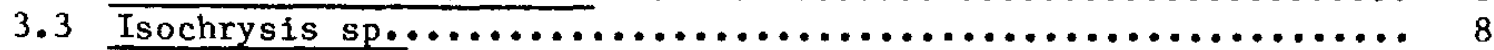

3.4 Nannochloropsis salina.............................. 10

3.5 Dunaliella salina............................... 10

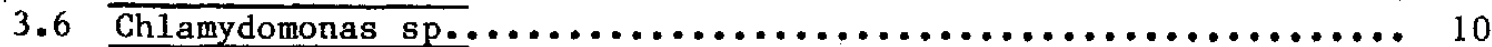

3.7 Cyclotella cryptica................................. 10

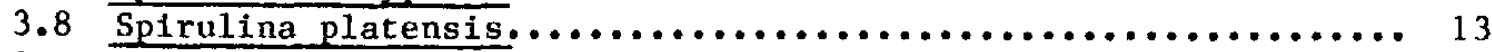

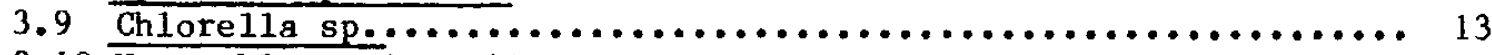

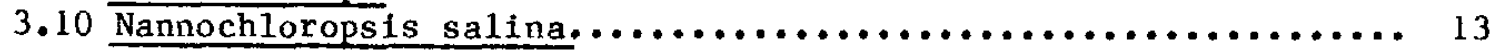

3.11 Dunaliella salina............................... 15

4.0 Discussion......................................... 18

5.0 Conclusions....................................... 19

6.0 References........................................ 23 


\section{LIST OF FIGURES}

Page

1-1 Microalgal Production and Products........................ 2

2-1 Ethanol Yield from Microalgae Biomass..................... 3

2-2 Hydrocarbon/Methyl Ester Yleld from Microalgae Biomass.......... 4

2-3 Methane Yield from Microalgal Biomass..................... 5

5-1 Gas vs. Fuel Production from Representative High-Lipid Producers.... 19

5-2 Gas vs. Fuel Production from Representative High-Carbohydrate Producers........................................... 20

5-3 Gas vs. Fue1 Production from Representative High-Protein Producers.. 21

\section{LIST OF TABLES}

3-1 Chemical Composition of Various Microalgae.................. 7

3-2 Fuel Production Options for Botryoccus braunif................ 9

3-3 Fuel Production 0ptions for Ankistrodesmus falcatus............. 9

3-4 Fue1 Production options for Isochrysis sp.................. 11

3-5 Fuel Production Options for Nannochloropsis salina.............. 11

3-6 Fue1 Production Options for Dunaliella salina................. 12

3-7 Fuel Production Options for Chlamydomonas sp................. 12

3-8 Fuel Production Options for Cyclotella cryptica................ 14

3-9 Fuel Production Options for Spirulina platensis................ 14

3-10 Fue1 Production Options for Chlorella..................... 15

3-11 Fuel Production Options for Nannochloropsia salina............. 15

3-12 Fuel Production Options for Dunallella salina................ 17 
SFR․ 


\section{SECTION 1.0}

\section{INTRODUCTION}

Photosynthetic organisms such as microalgae "fix" atmospheric carbon into the energy-storage components of their cell mass; i.e. protein, carbohydrate, and lipid. Under the limitations of current technology, algae can convert up to $15 \%$ of the photosynthetically available solar radiation (PAR), or roughly $6 \%$ of the total incident radiation, into new cell mass [1].

The conversion of solar energy into renewable liquid fuels and other products could become economically competitive with petroleum if research progress continues. The historical emphasis on high-energy lipids as the primary fuel products from microalgae was based on some species' ability to accumulate large quantities of these compounds, especially under stressful growth conditions [2]. The objective of this report is to examine the chemical makeup of a variety of algal species under different growth conditions and the conversion processes possible for each class of compounds (i.e., lipids, carbohydrates, and proteins). Based on the results of this analysis, some projections are made about the optimum fuel product conversion route(s) for several representative species.

As part of the Solar Energy Research Institute (SERI)/United States Department of Energy (DOE) Aquatic Species Program's major study of fuel products from microalgae, this report provides an important link between cultivation and harvesting of a variety of algal species and conversion of specific biochemical fractions into the desired products.

The recent work of Tornabene et al. and Ben-Amotz in characterizing different algae with respect to chemical composition, especially possible for each class of compounds (i.e., lipids, carbohydrates, and proteins). Based on the results of this analysis, some projections are made about the optimum fuel product conversion route(s) for several representative species.

As part of the Solar Energy Research Institute (SERI)/United States Department of Energy (DOE) Aquatic Species Program's major study of fuel products from microalgae, this report provides an important link between cultivation and harvesting of a variety of algal species and conversion of specific biochemical fractions into the desired products.

The recent work of Tornabene et al. and Ben-Amotz in characterizing different algae with respect to chemical composition, especially the lipid fractions, has been extremely valuable. Their reports $[3,4,5]$ discuss in detail materials and methods for these characterizations. Other sources of biochemical data may be found in Burlew [2]. The first step is to examine the total chemical composition and gross energy content of several representative species. The next level of consideration is to examine the crude lipid and carbohydrate components, followed by any subfractions for which data are avallable; e.g., the neutral lipid fraction extracted by hexane or the benzene-soluble fraction containing aromatics and carotenoids. 


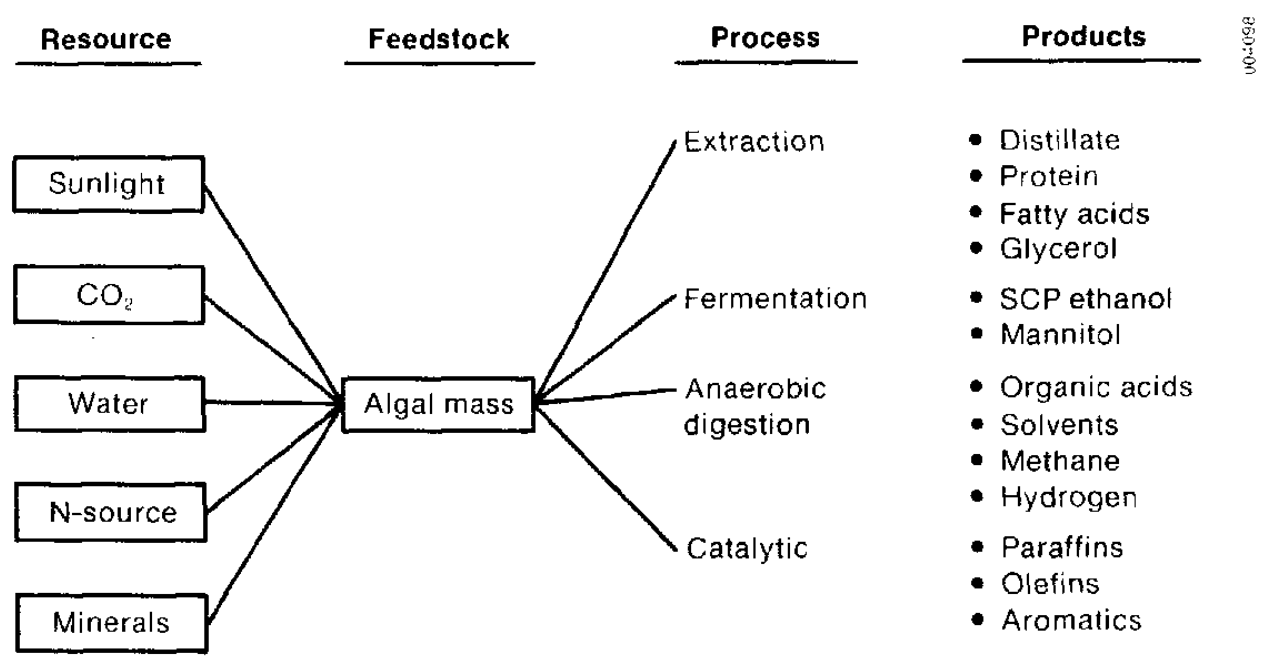

Figure 1-1. Microalgal Production and Products

It is beyond the scope of this report to consider all the potential conversion processes in detail with respect to process design and economics; however, a few process routes are considered, and each specie is evaluated to determine whether it might be a suitable feedstock. The process options considered are aerobic and anaerobic fermentation for carbohydrates, anaerobic fermentation only for proteins, and extraction and conversion processes in general and transesterification in particular for lipids. Figure 1-1 shows schematically how different conversion processes could produce a variety of fuel products from a microalgal feedstock. 


\section{SECTION 2.0}

\section{APPROACH}

Based on the reported algal composition, a gross energy content is calculated. "Typical" algal proteins are assumed to contain $23.86 \mathrm{MJ} / \mathrm{kg}(10,260 \mathrm{Btu} / \mathrm{lb})$; carbohydrates $15.92 \mathrm{MJ} / \mathrm{kg}(6840 \mathrm{Btu} / 1 \mathrm{~b})$; 1ipids $38.93 \mathrm{MJ} / \mathrm{kg}(16,740 \mathrm{Btu} / \mathrm{lb})$; and g1ycero1 $18.05 \mathrm{MJ} / \mathrm{kg}(7760 \mathrm{Btu} / 1 \mathrm{~b})[2]$.

In today's conventional ethanol fermentation, yeasts such as Saccharomyces cerevisiae can convert up to $95 \%$ of the "available" carbohydrate, i.e., glucose, into a $1: 1$ (weight) ratio of ethanol and carbon dioxide. The main requirement here is to estimate the available carbohydrate. Algal carbohydrates typically are complex mixtures of mono-, poly-, and olfgosaccharides, with pentoses and hexoses having been identified [2]. A reasonable approach is to assume that about two-thirds of the carbohydrate can be hydrolyzed to fermentable hexose monomer with the remainder essentially all pentose; i.e., not fermentable under current commercial practice. A combined hydrolysisfermentation yield of $80 \%$ is assumed for this carbohydrate fraction, which is much less homogeneous but more accessible to hydrolysis than, say, lignocellu1ose. These assumptions result in a net alcohol production of $0.329 \mathrm{~L} / \mathrm{kg}$ $(0.04 \mathrm{gal} / 1 \mathrm{~b})$ and a total energy content of $7.74 \mathrm{MJ} / \mathrm{kg}(3330 \mathrm{Btu} / 1 \mathrm{~b})$ of tota1 carbohydrate. Figure 2-1 shows the ethanol yield and energy production as functions of the carbohydrate content. A fermentation by-product, carbon dioxide (approximately $39 \mathrm{~L} / \mathrm{L}$ or $5.2 \mathrm{ft}^{3} / \mathrm{gal}$ of ethanol), is also produced.

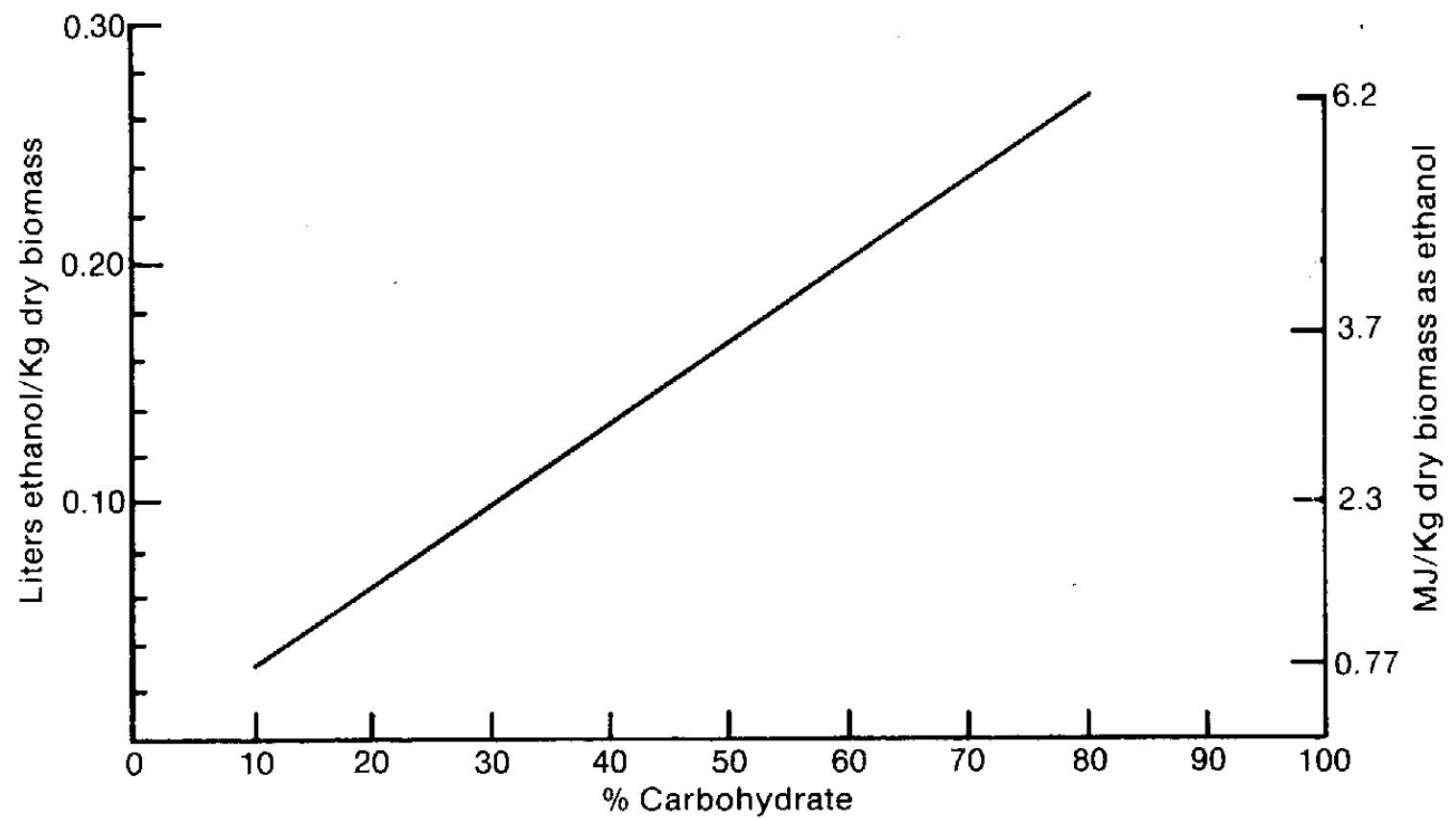

Figure 2-1. Bthanol Yield from Microalgae Bionass 
This screening study examines two lipid utilization routes: transesterification (conversion of triacylglycerols to monoesters of either methanol or ethano1) and a "simple" extraction of hydrocarbons. Based on data from Tornabene et al. [3], the hydrocarbon extraction calculations assume that the neutral lipids directly usable as fuel would be equal to the hexane extract plus one-half the benzene extract. In fact, the hydrocarbons of many species, at $28+$ carbons, may require cracking or other processing to insure their suitability. These fractions could be recovered with processing losses of only $2 \%$, yielding $1.15 \mathrm{~L}$ of hydrocarbon liquids per $\mathrm{kg}$ of lipid $(0.65 \mathrm{gal} / \mathrm{lb})$. Based on the energy content being equal to diesel fuel at $39 \mathrm{MJ} / \mathrm{L}$ $(129,500 \mathrm{Btu} / \mathrm{ga} 1), 44.96 \mathrm{MJ}(19,370 \mathrm{Btu})$ of energy per $\mathrm{kg}$ (1b) of lipid in the form of hydrocarbon could be recovered (Figure 2-2).

Transesterification, which is discussed in more detail elsewhere [6], produces a mixture of fatty acid esters, which have been shown to be suitable substitutes for diesel fuel. The assumed conversion of $95 \%$ of the triglycerides to fatty esters is routinely achieved in commercial processes. The critical parameter is the fraction of total lipids available for conversion; i.e., the triglyceride/fatty acid fraction. This fraction is estimated at $89 \%$ of the chloroform extract (exclusively triglyceride, converted to fatty acids) plus $65 \%$ of the methanol extract (phospholipids converted to fatty acids) [7]. Alternatively, in some cases the triglyceride/fatty acid contents have been reported directly. The ester fuel produced has an energy content of $35 \mathrm{MJ} / \mathrm{L}$ $(116,200 \mathrm{Btu} / \mathrm{ga1})$ or about $10 \%$ below that of diesel fuel [8]. These assumptions result in an ester fuel production of $1.25 \mathrm{~L} / \mathrm{kg}(0.73 \mathrm{gal} / \mathrm{lb})$ and an energy content of $43.8 \mathrm{MJ} / \mathrm{kg}(18,850 \mathrm{Btu} / 1 \mathrm{~b})$ of triglyceride (Figure 2-2).

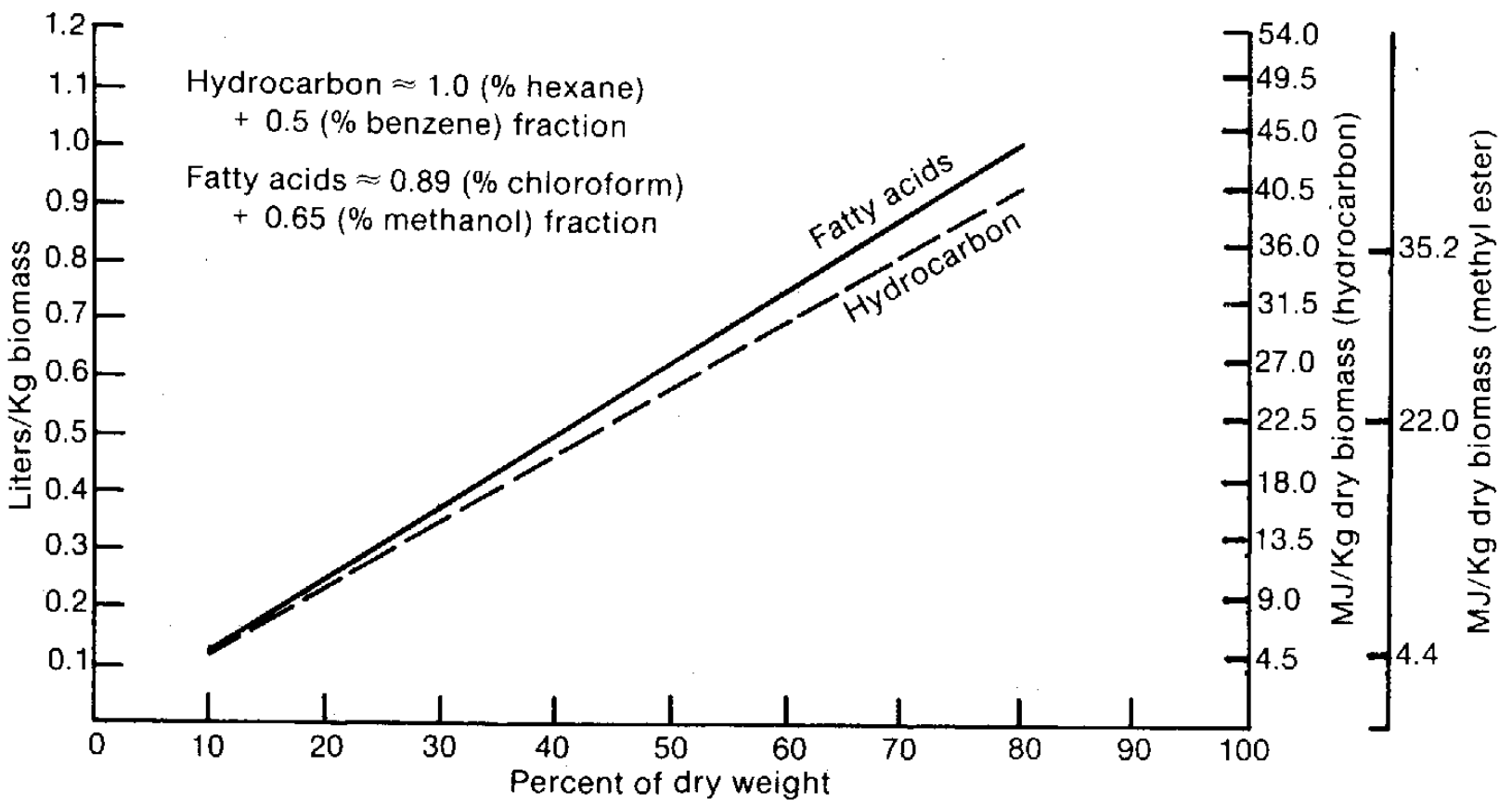

Figure 2-2. Hydrocarbon/Methyl Ester Yield from Microalgae Biomass 
Anaerobic digestion is the most flexible process in terms of available feedstocks. Basically, the entire organic weight, which was not used by one of the previously mentioned processes, is digested. The theoretical methane production rates [9] are $0.49 \mathrm{~m}^{3}$ of methane per $\mathrm{kg}$ of protein converted, $0.37 \mathrm{~m}^{3}$ per $\mathrm{kg}$ of carbohydrate, and $1.04 \mathrm{~m}^{3}$ per $\mathrm{kg}$ of lipid, and it is assumed that $80 \%$ of the volatile solids are converted to products ( $80 \%$ COD removal). The gaseous product is assumed to contain the typical biogas composition of $60 \%$ methane and $40 \%$ carbon dioxide. With an energy content of $37.2 \mathrm{MJ} / \mathrm{m}^{3}$ $\left(1000 \mathrm{Btu} / \mathrm{ft}^{3}\right)$ of methane, energy production per k1logram of volatile solids converted is $30.95 \mathrm{MJ} / \mathrm{kg}(9960 \mathrm{Btu} / \mathrm{lb}) 1 \mathrm{ipid}, 14.58 \mathrm{MJ} / \mathrm{kg}(4740 \mathrm{Btu} / \mathrm{lb})$ protein, and $11.01 \mathrm{MJ} / \mathrm{kg}$ ( $3600 \mathrm{Btu} / \mathrm{lb}$ ) carbohydrate (and glycerol). This information is shown graphically in Figure $2-3$.

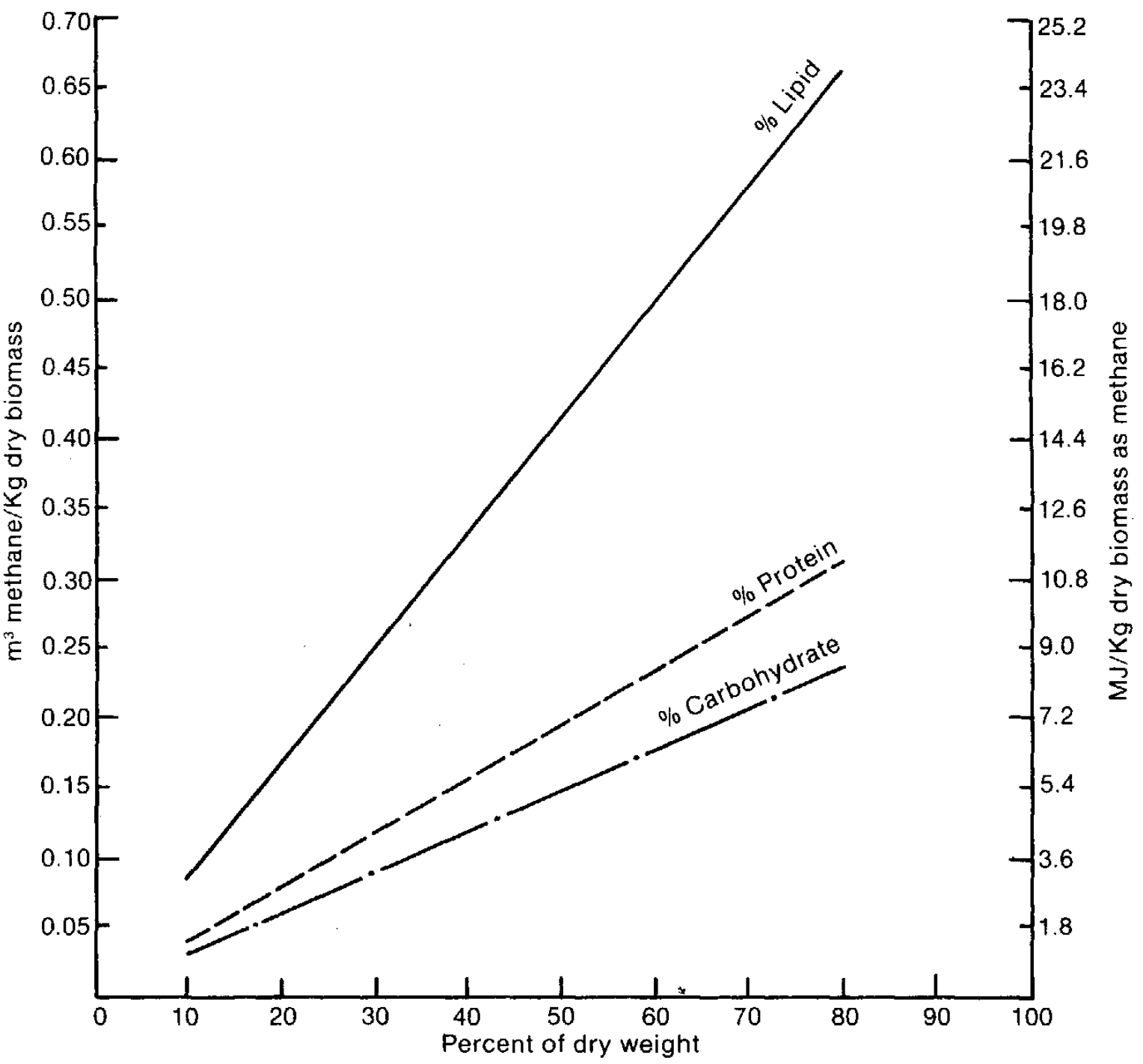

Figure 2-3. Methane Yield from Microalgal Biomass 
SECTION 3.0

FUEL OPTIONS AS DETERMTNED BY CHEMICAL COMPOSITION

Table 3-1 summarizes the chemical composition of representative algal species grown under a variety of nutrient and salinity conditions. The different species are grouped according to the primary products: lipids, carbohydrates, protein, and glycerol. The glycerol fraction could either be digested for gas or recovered as a by-product. For each species the amount of energy that can be converted to fuels and the fraction of the gross energy content are calculated in the following ways:

- Methane only: anaerobic digestion of the entire (ash-free) cell mass, including glycerol

- Methane-glycerol: anaerobic digestion of the cell mass, excluding glycerol

- Ester-methane: digestion of the protein and carbohydrate fractions only, with the lipids being converted to ester fuel and hydrocarbon

- Ethano1-methane: digestion of the protein and 1tpid fractions, with the carbohydrate being converted to ethanol

- Ester-ethanol-methane: digestion of the protein fraction only, with ester fuel, hydrocarbon, and ethanol production.

These are identified in Tables 3-2 through 3-12 as Options 1 through 5, respectively. All energy values are reported in $\mathrm{MJ} / \mathrm{kg}$ ash-free dry weight (multiply by 430 to convert to Btu/1b).

\section{3-1. Botryococcus braunif}

B. braunil, a slow-growing organism, is interesting because it accumulates a large fraction of its biomass as hydrocarbon/1ipid. Table 3-1 (Example 1) shows that under nitrogen-deficient growth conditions in fresh water, this organism accumulates lipids at $54.2 \%$ of ash-free dry weight. A sizeable protein-carbohydrate fraction, about $34 \%$, is also present. More than $53 \%$ of the total lipid content is benzene extractable and consists of aromatic hydrocarbons, which could be directly usable as fuels. Another $14.9 \%$ of total lipids are hexane-extractable, straight-chain alkanes (saturated hydrocarbons) primarily in the 30-32 carbon range. Coupled with this extremely high hydrocarbon content is a low fatty acid content estimated at $7.8 \%$ of the total 11pid. Examination of this fraction shows more than $55 \%$ to be saturated and singly unsaturated, indicating an ester fuel product relatively stable toward autooxidation during storage.

There is little question that this lipid content would be high enough to use the organism as a conversion feedstock if it could be grown at sufficiently high rates (Table 3-2). In general, the options that convert lipids to liquid fuels would be preferred, since more of the cell's energy is then recovered in the premium 1iquid form. An overall energy utilization rate of $75 \%$ can be achieved by anaerobic digestion of the lipid and protein fractions, and either 
Table 3-1. Chenical Composition of Various Microalgae

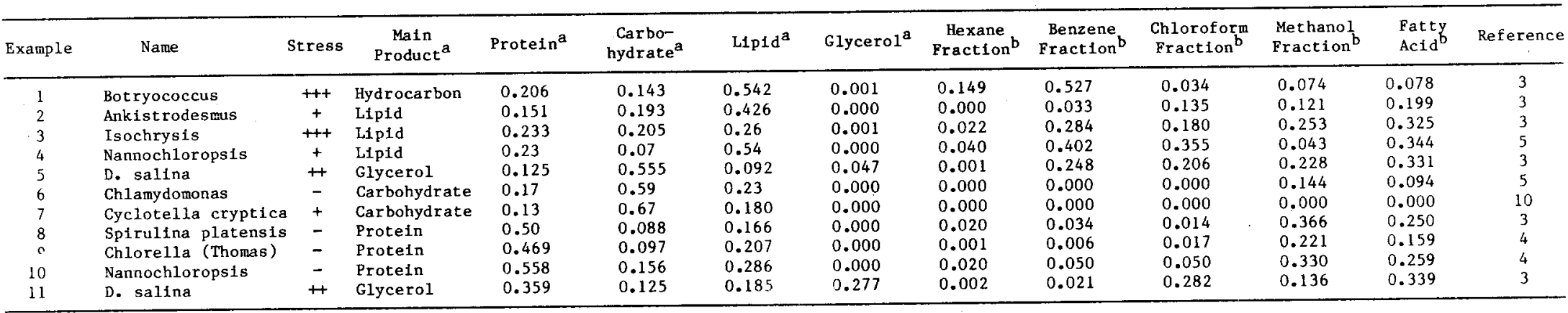

Legend:

- No stress

+ Nitrogen stress

++ Osmotic stress

+H Nitrogen and osmotic stress

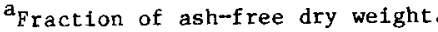

braction of total lipid. 
digestion or fermentation of the carbohydrate. Conversion of the lipids to 1iquid fuels (ester fuel and hydrocarbon) would recover $42 \%$ of the gross energy content in liquid form; fermentation would contribute another $5 \%$, for a liquid fuel utilization rate of $47 \%$ and an overall utilization rate of $58 \%$.

One of the key issues to be addressed by those wishing to cultivate this organism for fuel production would be: what are the limitations on the direct use of the hexane and benzene fractions as fuels? The predominance of saturated hydrocarbons with 30-32 carbons mentioned earlier may be too long for diesel fuel and possibly even for heavy fuel oils. An additional processing step might be required for conversion of part (or all) of the lipid fraction into usable liquid fuels. With this arguement the most critical question is whether a high enough growth rate can be maintained to enable these fuel options to be economically pursued.

\section{3-2. Ankistrodesmis falcatus}

The next high lipid-producing species considered is Ankistrodesmus falcatus, grown in nitrogen-deficient media. As shown in Table 3-1, more than $42 \%$ of the ash-free dry weight is lipid, with another $34 \%$ consisting of carbohydrate and protein. Unknown components represent a substantial 23\%. The hexane fraction is negligible and the benzene extract constitutes only $3.3 \%$ of total lipids. The chloroform (13.5\%) and methanol $(12.1 \%)$ are also sma11, resulting in a total fatty acid content of $19.9 \%$ of total lipids. Maximum overall fuel utilizations of approximately $75 \%$ are again achieved by anaerobic digestion, with or without fermentation. Conversion of triglycerides into ester fuel (without ethanol fermentation) produces both an overall energy utilzation rate (58.3\%) and a liquid fuel utilization (17.3\%) much lower than Botryococcus; inclusion of fermentation further reduces overall ut1lization to $34.9 \%$ but increases liquid fuel utilization to $25.5 \%$ (Table 3-3). These calculations show that high lipid content alone may not be indicative of a promising algal species if the right kind of lipids is not prevalent.

\section{3-3. Isochrysis sp.}

Example 3 shows the composition of an Isochrysis cultured under moderately saline $(0.5 \mathrm{M} \mathrm{NaCl})$, nitrogen-deficient conditions. Although the lipid content is a moderate $26 \%$, this organism is included among the high-lipid producers; 1ipid contents as high as $45 \%$ have been reported recently. Protein $(23 \%)$ and carbohydrate $(21 \%)$ are both substantial components. The hexane fraction represents $2.2 \%$ of total lipids, the benzene fraction $28.4 \%$, the chloroform fraction 18\%, and the methanol fraction $25.3 \%$ (total fatty acids $32.5 \%$ ). Tornabene has tentatively identified the major constituent of the benzene fraction as an oxygenated cyclic $\mathrm{C}-37$ isoprenoid chain, which could be significant either for fuels or by-products. Table 3-4 shows that the total energy content under these conditions is $18.9 \mathrm{MJ} / \mathrm{kg}$, considerably lower than the previous species. However, both the overall and liquid utilization efficiencies compare well with those of Botryococcus: the highest overall utilization is found in the methane-only option at $72.3 \%$, with the highest liquid fuel utilization found in the ester-ethanol-methane option with $40.3 \%$. The overall utilization rate of $58.2 \%$ is slightly higher than the corresponding utilization rate for Botryococcus. 
Table 3-2. Fue1 Production Options for Botryococcus braunii

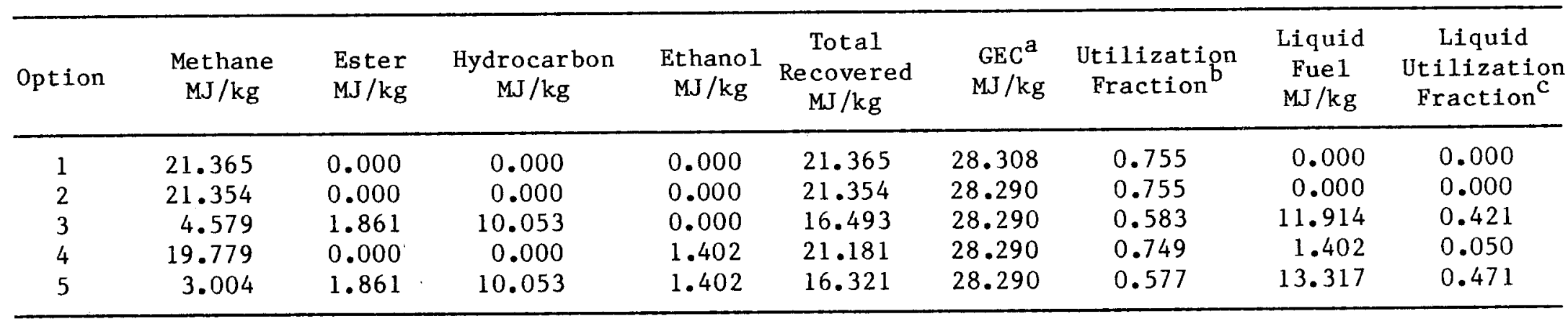

${ }^{a}$ Gross energy content, calculated as described in text.

$\mathrm{b}_{\text {Total }}$ recovered/GEC

$c_{\text {Liquid fuel/GEC }}$

Table 3-3. Fuel Production Options for Ankistrodesmus falcatus

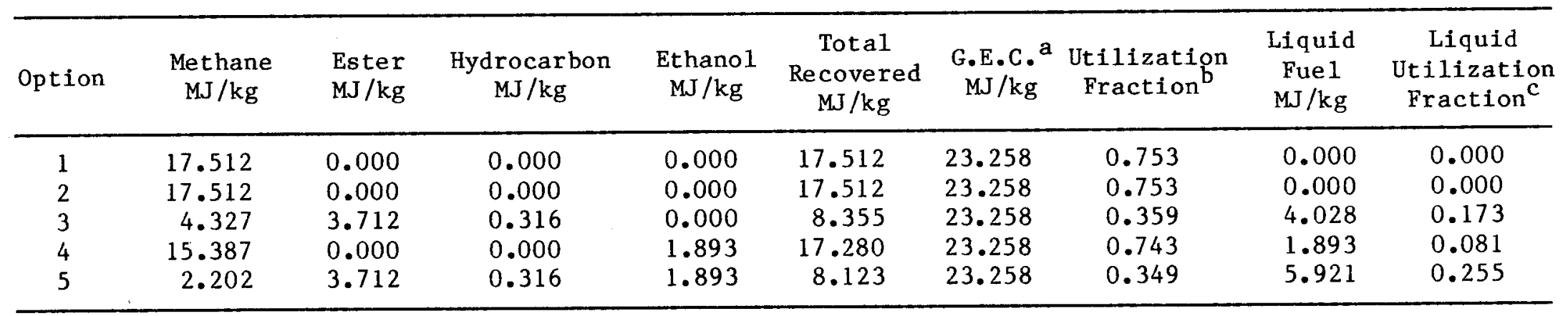

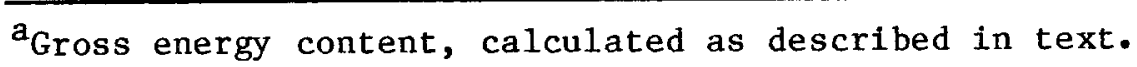

$b_{\text {Total }}$ recovered/GEC

$\mathrm{c}_{\text {Liquid fuel/GEC }}$ 


\section{3-4. Nannochloropsis salina (high 11pid)}

This organism when cultured in nitrogen-deficient seawater by Ben-Amotz developed high levels of total lipids (54\%). In particular the benzene (40.2\%) and chloroform (35.5\%) fractions were high [5]. Fatty acids are estimated at $34.4 \%$ of total 1ipids. A substantial carbohydrate fraction (23\%) is also present. The gross energy content at $27.6 \mathrm{MJ} / \mathrm{kg}$ is only slightly lower than that of Botryococcus. Once again, the anaerobic digestion options recover $75 \%$ of the gross energy content, with the ester-ethanol option having both a very good overall utilization rate $(62.3 \%)$ and a moderate liquid fuel utilization rate (53.1\%) (Table 3-5). The ester-ethanol-methane option could produce a greater amount of energy than could Botryococcus (18.0 vs. $16.3 \mathrm{MJ} / \mathrm{kg})$.

\section{3-5. Dunaliella salina (high carbohydrate)}

When subjected to both osmotic stress and nitrogen deficiency, Dunaliella salina produced large quantitles of carbohydrate. Listed as Example 5, this organism accumulated $55.5 \%$ of ash-free dry weight as carbohydrate. Both protein and carbohydrate were present at approximately $10 \%$, and glycerol (4.7\%) was also present, which will be discussed later (Example 11). The large carbohydrate content and small lipid content contribute to the gross energy content being considerably lower than the lipid-producers ( $16.2 \mathrm{MJ} / \mathrm{kg}$, including glycerol). The energy utilization rates (Table $3-6$ ) are also somewhat lower, especially in the methane options; less lipid and more carbohydrate to be digested means a lower net energy production. Liquid fuel utilization in the ester-ethanol-methane option for this organism $(47.4 \%)$ is comparable to the lipid producers; the difference is that $74 \%$ of the liquid fuel energy comes from ethanol. The methane-ethanol option, with an overall utilization rate of $65.7 \%$ and a liquid fue1 utilization rate of $35.4 \%$, might also be acceptable as a lower-cost alternative that still offers moderate liquid fuel production.

\section{3-6. Chlamydomonas sp.}

This organism was cultured by Ben-Amotz in seawater with no environmental stresses and is characterized by a high carbohydrate content (59\%) (Example 6). Lipid (23\%) and protein (17\%) contents were moderate, resulting in a gross energy content $(22.4 \mathrm{MJ} / \mathrm{kg})$ that compares favorably with the lipid producers (Table 3-7). The ethanol-methane option has a high overall utilization (68.7\%) and a moderate liquid fuel utilization (25.8\%), while the ester-ethanol-methane option has the lowest overall utilization (41.1\%) and a liquid fuel utflization (30\%) that does not compare favorably with other species. The overall utilization of $71.9 \%$ in the methane-only option is good, however.

\section{3-7. Cyclotella Cryptica}

This diatom, grown by Werner [10] in nftrogen-deffcient media, produced exceptional carbohydrate content $(67 \%)$. Lipid content is a moderate $18 \%$ (Example 7), which contributes to a gross energy content of $20.77 \mathrm{MJ} / \mathrm{kg}$. No 
Table 3-4. Fuel Production Options for Isochrysis sp.

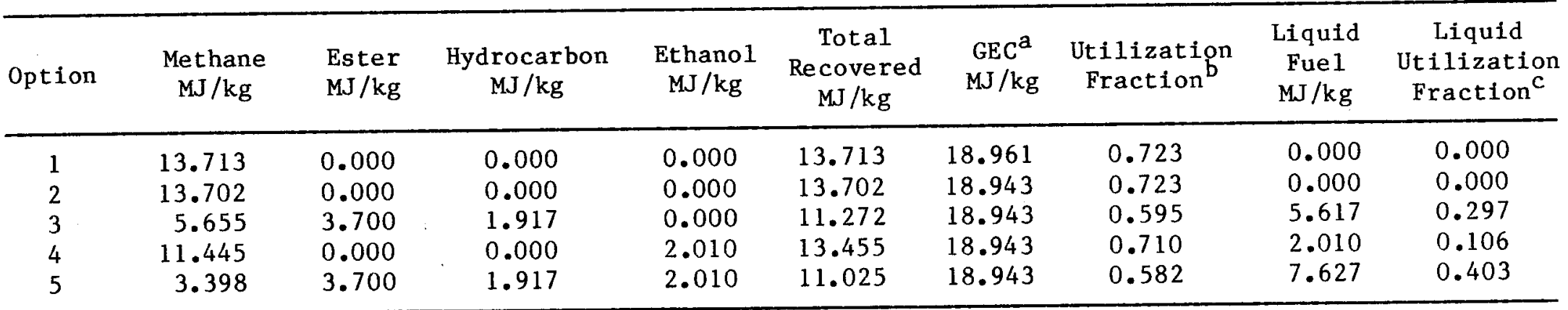

${ }^{a}$ Gross energy content, calculated as described in text.

botal recovered/GEC

$\mathrm{c}_{\text {Liquid fuel/GEC }}$

Table 3-5. Fuel Production Options for Nannochloropsis salina (high lipid)

\begin{tabular}{|c|c|c|c|c|c|c|c|c|c|}
\hline Option & $\begin{array}{l}\text { Methane } \\
\mathrm{MJ} / \mathrm{kg}\end{array}$ & $\begin{array}{l}\text { Ester } \\
\mathrm{MJ} / \mathrm{kg}\end{array}$ & $\begin{array}{c}\text { Hydrocarbon } \\
\mathrm{MJ} / \mathrm{kg}\end{array}$ & $\begin{array}{l}\text { Ethanol } \\
\mathrm{MJ} / \mathrm{kg}\end{array}$ & $\begin{array}{c}\text { Total } \\
\text { Recovered } \\
\mathrm{MJ} / \mathrm{kg}\end{array}$ & $\begin{array}{l}\mathrm{GEC}^{\mathrm{a}} \\
\mathrm{MJ} / \mathrm{kg}\end{array}$ & $\begin{array}{l}\text { Utilization } \\
\text { Fraction }\end{array}$ & $\begin{array}{l}\text { Liquid } \\
\text { Fue } 1 \\
\mathrm{MJ} / \mathrm{kg}\end{array}$ & $\begin{array}{c}\text { Liquid } \\
\text { Utilization } \\
\text { Fraction }\end{array}$ \\
\hline 1 & 20.838 & 0.000 & 0.000 & 0.000 & 20.838 & 27.624 & 0.754 & 0.000 & 0.000 \\
\hline 2 & 20.838 & 0.000 & 0.000 & 0.000 & 20.838 & 27.624 & 0.754 & 0.000 & 0.000 \\
\hline 3 & 4.125 & 8.139 & 5.852 & 0.000 & 18.116 & 27.624 & 0.656 & 13.991 & 0.506 \\
\hline 4 & 20.067 & 0.000 & 0.000 & 0.686 & 20.754 & 27.624 & 0.751 & .686 & 0.025 \\
\hline 5 & 3.354 & 8.139 & 5.852 & 0.686 & 18.032 & 27.624 & 0.653 & 14.678 & 0.531 \\
\hline
\end{tabular}

${ }^{a}$ Gross energy content, calculated as described in text.

$\mathrm{b}_{\text {Total }}$ recovered/GEC

$\mathrm{c}_{\text {Liquid fuel/GEC }}$ 
Table 3-6. Fuel Production Options for Dunaliella salina (high carbohydrate)

\begin{tabular}{|c|c|c|c|c|c|c|c|c|c|}
\hline Option & $\begin{array}{l}\text { Methane } \\
\mathrm{MJ} / \mathrm{kg}\end{array}$ & $\begin{array}{l}\text { Ester } \\
\mathrm{MJ} / \mathrm{kg}\end{array}$ & $\begin{array}{c}\text { Hydrocarbon } \\
\mathrm{MJ} / \mathrm{kg}\end{array}$ & $\begin{array}{l}\text { Ethanol } \\
\mathrm{MJ} / \mathrm{kg}\end{array}$ & $\begin{array}{c}\text { Total } \\
\text { Recovered } \\
\mathrm{MJ} / \mathrm{kg}\end{array}$ & $\begin{array}{l}\mathrm{GEC}^{\mathrm{a}} \\
\mathrm{MJ} / \mathrm{kg}\end{array}$ & $\begin{array}{l}\text { Utilization } \\
\text { Fraction }\end{array}$ & $\begin{array}{l}\text { Liquid } \\
\text { Fue1 } \\
\mathrm{MJ} / \mathrm{kg}\end{array}$ & $\begin{array}{c}\text { Liquid } \\
\text { Utilization } \\
\text { Fraction }\end{array}$ \\
\hline 1 & 11.299 & 0.000 & 0.000 & 0.000 & 11.299 & 16.242 & 0.696 & 0.000 & 0.000 \\
\hline 2 & 10.781 & 0.000 & 0.000 & 0.000 & 10.781 & 15.394 & 0.700 & 0.000 & 0.000 \\
\hline 3 & 7.934 & 1.337 & 0.517 & 0.000 & 9.788 & 15.394 & 0.636 & 1.854 & 0.120 \\
\hline 4 & 4.670 & 0.000 & 0.000 & 5.443 & 10.113 & 15.394 & 0.657 & 5.443 & 0.354 \\
\hline 5 & 1.823 & 1.337 & 0.517 & 5.443 & 9.120 & 15.394 & 0.592 & 7.297 & 0.474 \\
\hline
\end{tabular}

${ }^{a}$ Gross energy content, calculated as described in text.

$\mathrm{b}_{\text {Total }}$ recovered/GEC

${ }^{c_{\text {Liquid fuel/GEC }}}$

Table 3-7. Fuel Production Options for Chlamydomonas sp.

\begin{tabular}{|c|c|c|c|c|c|c|c|c|c|}
\hline Option & $\begin{array}{l}\text { Methane } \\
\mathrm{MJ} / \mathrm{kg}\end{array}$ & $\begin{array}{l}\text { Ester } \\
\mathrm{MJ} / \mathrm{kg}\end{array}$ & $\begin{array}{c}\text { Hydrocarbon } \\
\mathrm{MJ} / \mathrm{kg}\end{array}$ & $\begin{array}{l}\text { Ethanol } \\
\mathrm{MJ} / \mathrm{kg}\end{array}$ & $\begin{array}{l}\text { Total } \\
\text { Recovered } \\
\mathrm{MJ} / \mathrm{kg}\end{array}$ & $\begin{array}{l}\mathrm{GEC}^{\mathrm{a}} \\
\mathrm{MJ} / \mathrm{kg}\end{array}$ & $\begin{array}{l}\text { Utilization } \\
\text { Fractionb }\end{array}$ & $\begin{array}{l}\text { Liquid } \\
\text { Fue1 } \\
\mathrm{MJ} / \mathrm{kg}\end{array}$ & $\begin{array}{c}\text { Liquid } \\
\text { Utilization } \\
\text { Fraction }\end{array}$ \\
\hline 1 & 16.094 & 0.000 & 0.000 & 0.000 & 16.094 & 22.397 & 0.719 & 0.000 & 0.000 \\
\hline 2 & 16.094 & 0.000 & 0.000 & 0.000 & 16.094 & 22.397 & 0.719 & 0.000 & 0.000 \\
\hline 3 & 8.976 & 0.944 & 0.000 & 0.000 & 9.919 & 22.397 & 0.443 & 0.944 & 0.042 \\
\hline 4 & 9.598 & 0.000 & 0.000 & 5.786 & 15.384 & 22.397 & 0.687 & 5.786 & 0.258 \\
\hline 5 & 2.479 & 0.944 & 0.000 & 5.786 & 9.209 & 22.397 & 0.411 & 6.730 & 0.300 \\
\hline
\end{tabular}

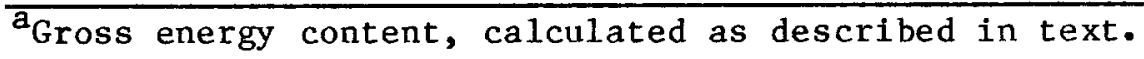

$b_{\text {Total }}$ recovered/GEC

$\mathrm{c}_{\text {Liquid fue } 1 / G E C}$ 
data is available on lipid subfractions, so digestion is essentially the only lipid utilization option considered. As Table 3-8 shows, the overall energy utilization rate is $71.5 \%$ in the methane-only option, and drops only to $67.6 \%$ in the ethanol-methane option. Liquid fuel utilization efficiency is $31.6 \%$, which is close to that of D. salina (Example 5) for this option. Each of the three representative carbohydrate-producing spectes has a particular characteristic to recommend it: Dunaliella has the highest liquid fuel utillzation rate $(35.4 \%$ in the ester-ethano1-methane option); Chlamydomonas has the highest gross energy content $(22.4 \mathrm{MJ} / \mathrm{kg})$, resulting in the highest energy production values (up to $16.1 \mathrm{MJ} / \mathrm{kg}$ ); and Cyclotella has extremely high carbohydrate content, resulting in the highest ethanol production $(6.6 \mathrm{MJ} / \mathrm{kg}$ ash-free dry weight).

\section{3-8. Spirulina platensis}

Spirulina sp. has been cultivated for commercial protein production. Cultivated by Tornabene et a1. in an unstressed environment [3], the organism produced $50 \%$ of its cell weight as protein (Example 8 ), with a moderate (16.6\%) lipid content, of which $5.4 \%$ was in the hexane and benzene fractions and $38 \%$ in the chloroform and methanol fractions (fatty acids estimated at 25\%). With the slightly higher energy content of protein versus carbohydrate, a gross energy content of $19.8 \mathrm{MJ} / \mathrm{kg}$ of dry biomass is calculated (Table 3-9). As discussed earlier, the only method considered here for using the protein fraction for fuel production is anaerobic digestion. Examination of all the fuelproducing options shows the methane-only option to have the highest overall utilization rate $(67.7 \%$ ), with both ester-producing options (with and without ethanol production) having overall utilization rates at approximately $52 \%$ and liquid fuel utilization rates at $10 \%-15 \%$.

\section{3-9. Chlore11a sp.}

Example 9 of Table 3-1 shows a Chlorella that was isolated from desert saline waters [4]. It was high in protein (45.9\%), moderate in lipid $(20.7 \%)$, and low in carbohydrate ( $9.7 \%)$. Neutral lipids totaled only $2.3 \%$ of total lipids, and fatty acids were estimated at $15.9 \%$. Gross energy content was calculated at $20.8 \mathrm{MJ} / \mathrm{kg}$ ( Table 3-10), and energy utilization ranged from $51.8 \%$ for the ester-ethano1-methane option (with a liquid fuel utilization rate of $11.7 \%$ ) to $68.8 \%$ for the methane-only option.

\section{3-10. Nannochloropsis salina (high protein)}

This organism has been shown to be a potential high-lipid producer when subjected to environmental stress (Example 4); however, Nannochloropsis produces high protein content in the absence of stresses (Example 10). With a protein content of $55.8 \%$, 1ipid content of $28.6 \%$, and a carbohydrate content of $15.6 \%$, Nannochloropsis has a gross energy content of $26.9 \mathrm{MJ} / \mathrm{kg}$, the highest of the protein-producing species (Table 3-11). The methane-only option has an energy utilization rate of $69.5 \%$, and both ester-methane options (with and without fermentation) have overall utilization rates of approximately $50 \%$ and liquid 
Table 3-8. Fuel Production Options for Cyclotella cryptica

\begin{tabular}{|c|c|c|c|c|c|c|c|c|c|}
\hline Option & $\begin{array}{l}\text { Methane } \\
\mathrm{MJ} / \mathrm{kg}\end{array}$ & $\begin{array}{l}\text { Ester } \\
\mathrm{MJ} / \mathrm{kg}\end{array}$ & $\begin{array}{l}\text { Hydrocarbon } \\
\mathrm{MJ} / \mathrm{kg}\end{array}$ & $\begin{array}{c}\text { Ethanol } \\
\mathrm{MJ} / \mathrm{kg}\end{array}$ & $\begin{array}{c}\text { Total } \\
\text { Recovered } \\
\mathrm{MJ} / \mathrm{kg}\end{array}$ & $\begin{array}{l}\mathrm{GEC}^{\mathrm{a}} \\
\mathrm{MJ} / \mathrm{kg}\end{array}$ & $\begin{array}{l}\text { Utilization } \\
\text { Fraction }\end{array}$ & $\begin{array}{l}\text { Liquid } \\
\text { Fue1 } \\
\mathrm{MJ} / \mathrm{kg}\end{array}$ & $\begin{array}{c}\text { Liquid } \\
\text { Utilization } \\
\text { Fractionc }\end{array}$ \\
\hline 1 & 14.844 & 0.000 & 0.000 & 0.000 & 14.844 & 20.769 & 0.715 & 0.000 & 0.000 \\
\hline 2 & 14.844 & 0.000 & 0.000 & 0.000 & 14.844 & 20.769 & 0.715 & 0.000 & 0.000 \\
\hline 3 & 9.273 & 0.000 & 0.000 & 0.000 & 9.273 & 20.769 & 0.446 & 0.000 & 0.000 \\
\hline 4 & 7.467 & 0.000 & 0.000 & 6.571 & 14.037 & 20.769 & 0.676 & 6.571 & 0.316 \\
\hline 5 & 1.896 & 0.000 & 0.000 & 6.571 & 8.466 & 20.769 & 0.408 & 6.571 & 0.316 \\
\hline
\end{tabular}

${ }^{a}$ Gross energy content, calculated as described in text.

$b_{\text {Total }}$ recovered/GEC

$\mathrm{C}_{\text {Liquid fuel/GEC }}$

Table 3-9. Fuel Production Options for Spirulina platensis

\begin{tabular}{|c|c|c|c|c|c|c|c|c|c|}
\hline Option & $\begin{array}{l}\text { Methane } \\
\mathrm{MJ} / \mathrm{kg}\end{array}$ & $\begin{array}{l}\text { Ester } \\
\mathrm{MJ} / \mathrm{kg}\end{array}$ & $\begin{array}{c}\text { Hydrocarbon } \\
\mathrm{MJ} / \mathrm{kg}\end{array}$ & $\begin{array}{c}\text { Ethano1 } \\
\mathrm{MJ} / \mathrm{kg}\end{array}$ & $\begin{array}{c}\text { Total } \\
\text { Recovered } \\
\mathrm{MJ} / \mathrm{kg}\end{array}$ & $\begin{array}{c}\mathrm{GEC}^{\mathrm{a}} \\
\mathrm{MJ} / \mathrm{kg}\end{array}$ & $\begin{array}{l}\text { Utilization } \\
\text { Fraction }\end{array}$ & $\begin{array}{l}\text { Liquid } \\
\text { Fue I } \\
\mathrm{MJ} / \mathrm{kg}\end{array}$ & $\begin{array}{c}\text { Liquid } \\
\text { Utilization } \\
\text { Fraction }\end{array}$ \\
\hline 1 & 13.398 & 0.000 & 0.000 & 0.000 & 13.398 & 19.792 & 0.677 & 0.000 & 0.000 \\
\hline 2 & 13.398 & $0.000^{*}$ & 0.000 & 0.000 & 13.398 & 19.792 & 0.677 & 0.000 & 0.000 \\
\hline 3 & 8.260 & 1.822 & 0.276 & 0.000 & 10.358 & 19.792 & 0.523 & 2.098 & 0.106 \\
\hline 4 & 12.429 & 0.000 & 0.000 & 0.863 & 13.292 & 19.792 & 0.672 & 0.863 & 0.044 \\
\hline 5 & 7.291 & 1.822 & 0.276 & 0.863 & 10.252 & 19.792 & 0.518 & 2.961 & 0.150 \\
\hline
\end{tabular}

${ }^{a}$ Gross energy content, calculated as described in text.

$b_{\text {Total }}$ recovered/GEC

$\mathrm{c}_{\text {Liquid fuel/GEC }}$ 
Table 3-10. Fuel Production Options for Chlorella (Thomas)

\begin{tabular}{cccccccccc}
\hline Option & $\begin{array}{c}\text { Methane } \\
\text { MJ/kg }\end{array}$ & $\begin{array}{c}\text { Ester } \\
\text { MJ/kg }\end{array}$ & $\begin{array}{c}\text { Hydrocarbon } \\
\text { MJ/kg }\end{array}$ & $\begin{array}{c}\text { Ethanol } \\
\text { MJ/kg }\end{array}$ & $\begin{array}{c}\text { Total } \\
\text { Recovered } \\
\text { MJ/kg }\end{array}$ & $\begin{array}{c}\text { GEC }^{\text {MJ } / \mathrm{kg}} \\
\text { Fraction }\end{array}$ & $\begin{array}{c}\text { Utilization } \\
\text { Fraquid } \\
\text { Fuel } \\
\text { MJ/kg }\end{array}$ & $\begin{array}{c}\text { Liquid } \\
\text { Utilization } \\
\text { Fraction }\end{array}$ \\
\hline 1 & 14.314 & 0.000 & 0.000 & 0.000 & 14.314 & 20.792 & 0.688 & 0.000 & 0.000 \\
2 & 14.314 & 0.000 & 0.000 & 0.000 & 14.314 & 20.792 & 0.688 & 0.000 & 0.000 \\
3 & 7.907 & 1.441 & 0.037 & 0.000 & 9.385 & 20.792 & 0.451 & 1.478 & 0.071 \\
4 & 13.246 & 0.000 & 0.000 & 0.951 & 14.197 & 20.792 & 0.683 & 0.951 & 0.046 \\
5 & 6.839 & 1.441 & 0.037 & 0.951 & 9.268 & 20.792 & 0.446 & 2.429 & 0.117 \\
\hline
\end{tabular}

${ }^{a}$ Gross energy content, calculated as described in text.

b Total recovered/GEC

$\mathrm{c}_{\text {Liquid fuel/GEC }}$

Table 3-11. Fuel Production Options for Nannochloropsis salina (high protein)

\begin{tabular}{|c|c|c|c|c|c|c|c|c|c|}
\hline Option & $\begin{array}{l}\text { Methane } \\
\mathrm{MJ} / \mathrm{kg}\end{array}$ & $\begin{array}{l}\text { Ester } \\
\mathrm{MJ} / \mathrm{kg}\end{array}$ & $\begin{array}{l}\text { Hydrocarbon } \\
\mathrm{MJ} / \mathrm{kg}\end{array}$ & $\begin{array}{c}\text { Ethano1 } \\
\mathrm{MJ} / \mathrm{kg}\end{array}$ & $\begin{array}{c}\text { Total } \\
\text { Recovered } \\
\mathrm{MJ} / \mathrm{kg}\end{array}$ & $\begin{array}{l}\mathrm{GEC}^{\mathrm{a}} \\
\mathrm{MJ} / \mathrm{kg}\end{array}$ & $\begin{array}{l}\text { Utilization } \\
\text { Fraction }\end{array}$ & $\begin{array}{l}\text { Liquid } \\
\text { Fuel } \\
\mathrm{MJ} / \mathrm{kg}\end{array}$ & $\begin{array}{c}\text { Liquid } \\
\text { Utilization } \\
\text { Fractionc }\end{array}$ \\
\hline 1 & 18.707 & 0.000 & 0.000 & 0.000 & 18.707 & 26.930 & 0.695 & 0.000 & 0.000 \\
\hline 2 & 18.707 & 0.000 & 0.000 & 0.000 & 18.707 & 26.930 & 0.695 & 0.000 & 0.000 \\
\hline 3 & 9.855 & 3.247 & 0.579 & 0.000 & 13.680 & 26.930 & 0.508 & 3.825 & 0.142 \\
\hline 4 & 16.989 & 0.000 & 0.000 & 1.530 & 18.519 & 26.930 & 0.688 & 1.530 & 0.057 \\
\hline 5 & 8.137 & 3.247 & 0.579 & 1.530 & 13.492 & 26.930 & 0.501 & 5.355 & 0.199 \\
\hline
\end{tabular}

${ }^{a}$ Gross energy content, calculated as described in text.

$\mathrm{b}_{\text {Total }}$ recovered/GEC

$\mathrm{c}_{\text {Liquid fue } 1 / \mathrm{GEC}}$ 
fuel utilization rates of $15 \%-20 \%$. All of these results are highest of the protein producers examined. The ester fuel $(3.25 \mathrm{MJ} / \mathrm{kg})$ and total lipid $(3.83 \mathrm{MJ} / \mathrm{kg})$ components of the net energy output are both quite high for what are essentially secondary products.

\section{3-11. Dunaliella salina (high glycerol)}

Example 11 in Table 3-1 shows the composition of D. salina grown in a saltstressed environment. Instead of principally carbohydrate as in optimal culture conditions (Example 5), the organism now produces a substantial quantity (27.7\%) of glycerol. The major product by weight is protein (35\%), with lesser amounts of lipid $(18.5 \%)$ and carbohydrate $(12.5 \%)$. Without going into great detail, a few important properties of glycerol should be noted. Glycerol is a commodity chemical (approximately 175,000 tons/yr) used in the food processing, cosmetic, and pharmaceutical industries, among others. A clear, high-boiling, viscous liquid, it is a member of the "generally regarded as safe" list, which makes its use common in the above applications. Another important property is that it is primarlly a natural product; petroleum-based glycerol has always been more expensive than natural glycerol produced as a by-product of soap manufacture. It is thought that the ability of this organism to accumulate large quantities of glycerol could be put to economic advantage. This assertion would need to be tested in some detail by analysis that is beyond the present scope.

Table 3-12 summarizes the energy recovery potential from this organism. of the gross energy content of $22.8 \mathrm{MJ} / \mathrm{kg}, 5 \mathrm{MJ}$ or $22 \%$ is due to the glycerol content. Extraction of the glycerol for use of its potential by-product value actually increases the overall utilization efficiency from $67.6 \%$ in the methane-only option (which includes digestion of the glycerol to methane) to $69.5 \%$ in the methane-glycerol option. W1thout the fuel value of the glycerol, the gross energy content is a somewhat 1 ow $17.8 \mathrm{MJ} / \mathrm{kg}$, but overall utilization rates are approximately $53 \%$ in the ester fuel-methane and ester-methaneethanol options. Liquid fuel utilization ranges from $16 \%$ without fermentation to $23 \%$ with it. A final note of emphasis should be added concerning the potential economic benefit of glycerol as a by-product. 
Table 3-12. Fuel Production Options for Dunaliella sallna (high-glycero1)

\begin{tabular}{|c|c|c|c|c|c|c|c|c|c|}
\hline Option & $\begin{array}{l}\text { Methane } \\
\mathrm{MJ} / \mathrm{kg}\end{array}$ & $\begin{array}{l}\text { Ester } \\
\mathrm{MJ} / \mathrm{kg}\end{array}$ & $\begin{array}{c}\text { Hydrocarbon } \\
\mathrm{MJ} / \mathrm{kg}\end{array}$ & $\begin{array}{c}\text { Ethano1 } \\
\mathrm{MJ} / \mathrm{kg}\end{array}$ & $\begin{array}{c}\text { Total } \\
\text { Re covered } \\
\mathrm{MJ} / \mathrm{kg}\end{array}$ & $\begin{array}{l}\mathrm{GEC}^{\mathrm{a}} \\
\mathrm{MJ} / \mathrm{kg}\end{array}$ & $\begin{array}{l}\text { Utilization } \\
\text { Fraction }\end{array}$ & $\begin{array}{l}\text { Liquid } \\
\text { Fuel } \\
\mathrm{MJ} / \mathrm{kg}\end{array}$ & $\begin{array}{c}\text { Liquid } \\
\text { Utilization } \\
\text { Fraction }\end{array}$ \\
\hline 1 & 15.387 & 0.000 & 0.000 & 0.000 & 15.387 & 22.756 & 0.676 & 0.000 & 0.000 \\
\hline 2 & 12.337 & 0.000 & 0.000 & 0.000 & 12.337 & 17.757 & 0.695 & 0.000 & 0.000 \\
\hline 3 & 6.611 & 2.752 & 0.104 & 0.000 & 9.467 & 17.757 & 0.533 & 2.856 & 0.161 \\
\hline 4 & 10.961 & 0.000 & 0.000 & 1.226 & 12.187 & 17.757 & 0.686 & 1.226 & 0.069 \\
\hline 5 & 5.235 & 2.752 & 0.104 & 1.226 & 9.317 & 17.757 & 0.525 & 4.082 & 0.230 \\
\hline
\end{tabular}

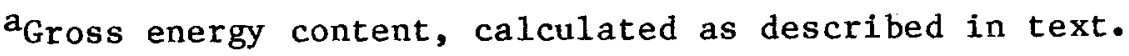

$b_{\text {Tota1 }}$ recovered/GEC

${ }^{c_{L i q u i d}}$ fuel/GEC 


\section{SECTION 4.0}

\section{DISCUSSION}

It is clear even from this limited-scope review that a number of microalgae represent potential sources of renewable energy. Many of the significant con pounds found in a barrel of crude oil may also be found in or be produced from algal lipids. Biochemical characterizations have indicated a wide range of potential products from microalgae, this slate being dependent on the particular strain of algae and the conditions under which that strain was grown. What needs to be immediately addressed is whether the product slate of a particular species can be maintained (or even achieved) in outdoor mass culture for production of large quantities of renewable fuel products.

The petroleum industry over a period of decades has developed a series of flexible downstream processing options that produce maximum amounts of gasoline during certain seasons of the year (or eertain economic conditions) or fuel oils at other times. The achievement of a similar state of affairs with microalgae, though a long way off, does appear feasible. If the kind of compositional variability observed in many species when culture conditions change is the rule rather than the exception, then that kind of flexibflity will be a necessity. When lipids or carbohydrates predominate, they would be economically recovered; when not, anaerobic digestion offers an alternative way to produce energy. A culture system where algal composition is continuously monitored for this kind of variation, followed by changes to the production schemes and the product slates, is easy to imagine. 
SECTION 5.0

\section{CONCLUSIONS}

Many of the species considered here have potential to become superior biomass feedstocks. Figure 5-1 shows the high lipid-producing organisms. Botryococcus braunii with its high hydrocarbon production $(10.1 \mathrm{MJ} / \mathrm{kg})$ and Nannochloropsis salina with high ester fuel production $(8.1 \mathrm{MJ} / \mathrm{kg})$ are the most promising. Ankistrodesmus and Isochrysis appear less promising based on these

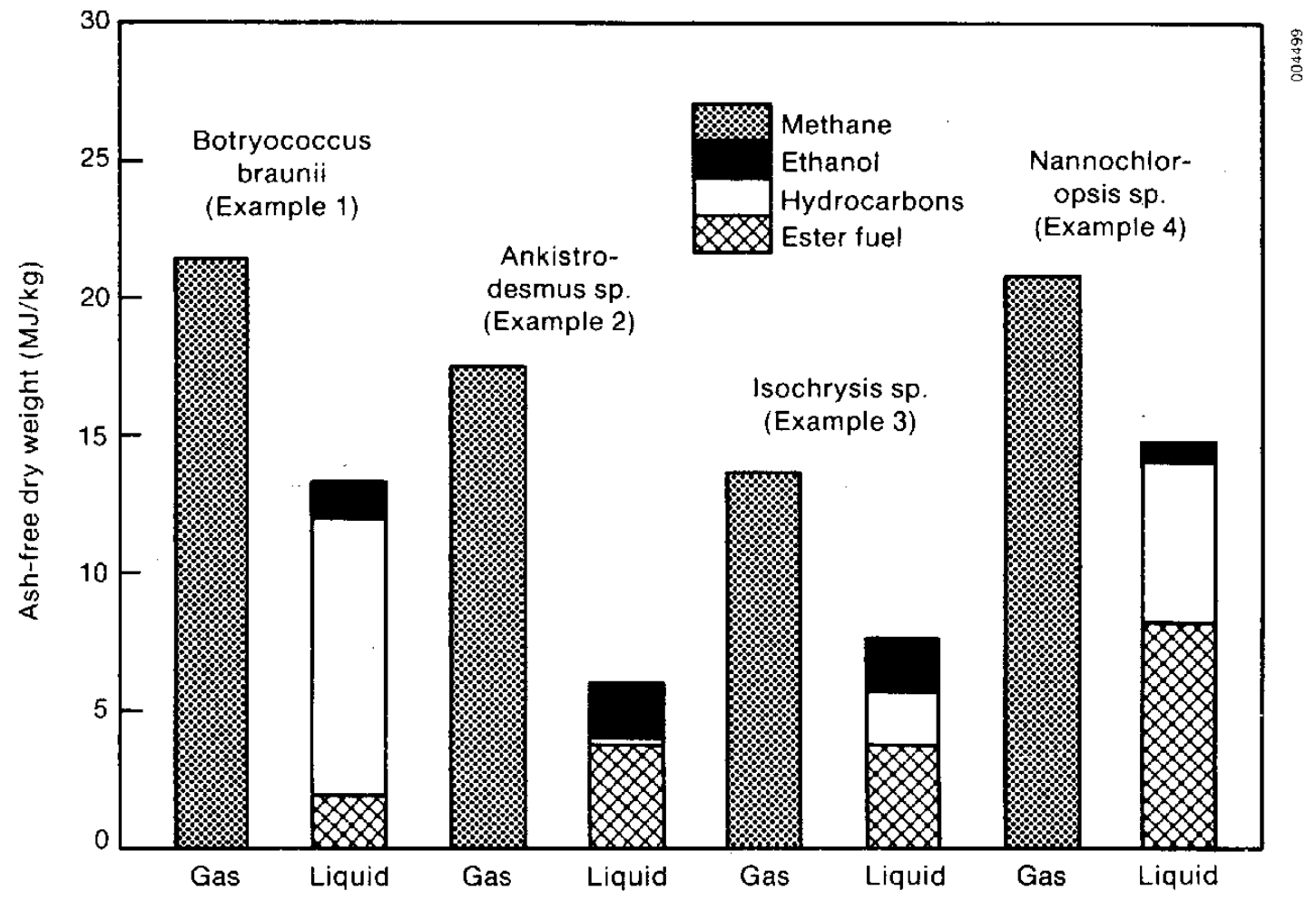

Figure 5-1. Gas vs. Fuel Production from Representative High-Lipid Producers 
data, but continued research could result in improvements to productivity, lipid content, or other factors. The results of this analysis seem to favor neutral lipids, whose energy is recoverable with minimal processing losses. Further analysis is required to determine which species could be economically produced, then where the economic trade-offs lie between anaerobic digestion and the liquid fuel options such as transesterification.

Figure 5-2 summarizes the results for the carbohydrate producers. Data for Dunaliella salina are shown for the high-carbohydrate and high-glycerol producing strains. The former has the lowest gross energy content and overall

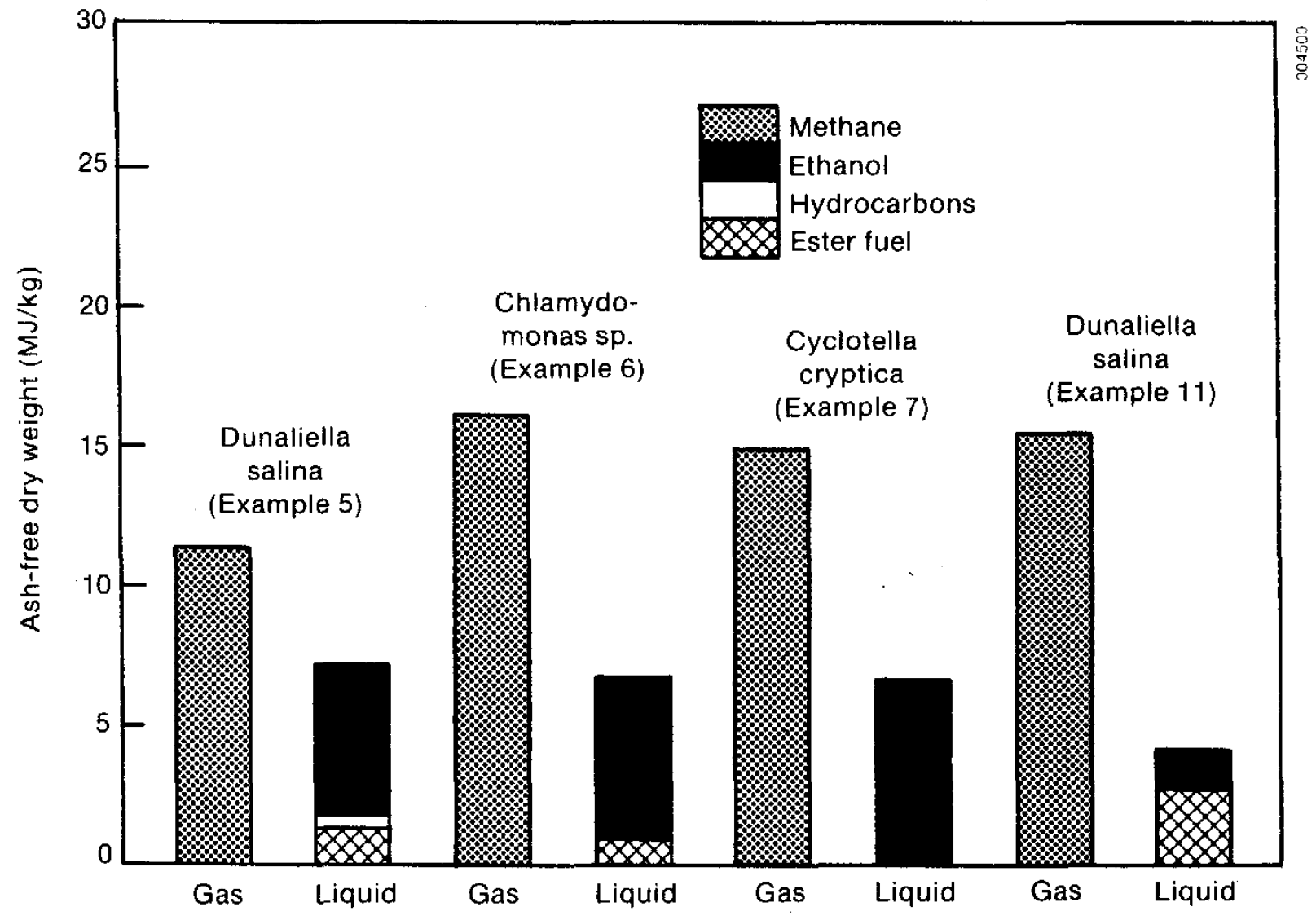

Figure 5-2. 'Gas vs. Liquid Puel Production from Representative HighCarbohydrate Producers 
energy utilization but the highest liquid fuel production and utilization data due to its relatively high proportion of fatty acids. The diatom Cyclotella cryptica has the highest ethanol production and highest carbohydrate content, and Chlamydomonas, with the highest lipid content, has the highest gross energy content and highest overall utilization efficiency. It should be recalled that the standard set of assumptions made about carbohydrates leads each species equally from carbohydrate to ethanol; characterizations of each species' carbohydrates are required to differentiate them.

Figure 5-3 shows graphically the energy data for the high protein-producing species. Nannochloropsis salina, with the highest lipid content; achieves the

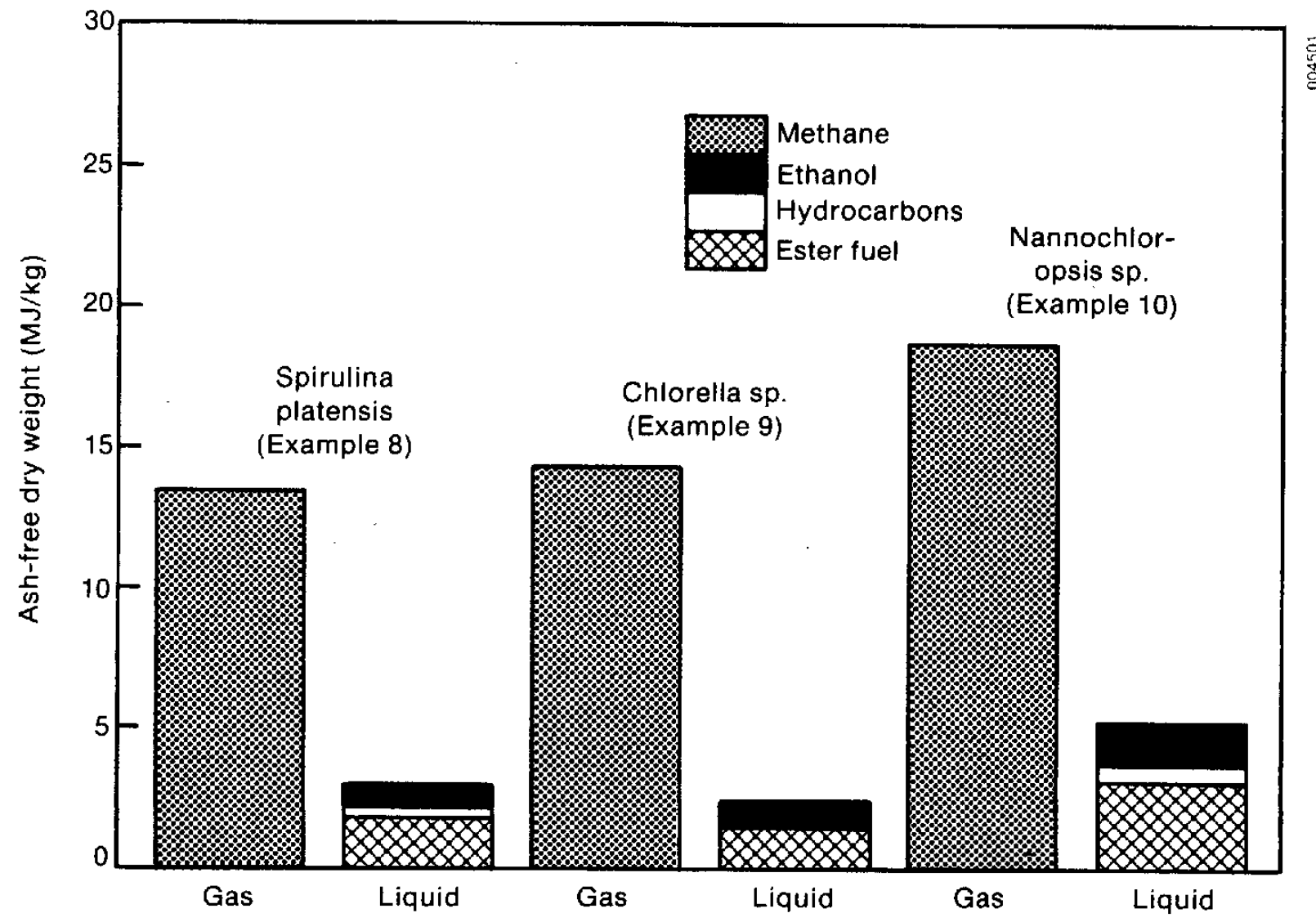

Figure 5-3. Gas vs. Liquid Fuel Production from Representative High-Protein Producers 
highest gross energy content and the highest individual production values for all the products examined (methane, ester fuel, hydrocarbons, and ethanol). This organism also has the highest overall utilization efficiencies in its methane-only option. Spirulina platensis has higher overall utilization efficiencies in integrated liquid-gaseous fuel processing options, while the Chlorella strain examined here shows slightly less promise than the others.

A few quick points should be made in summary. The only cases we have seen where lipid conversion routes are clearly the best choice are in the cases of extremely high lipid content coupled with very high fractions of either neutral lipids or fatty acids. Species with more moderate lipid content await the results of more detailed examination of the processing options, e.g., transesterification. Similarly, more detailed process design information will be required for comparison of fermentation with anaerobic digestion with regard to the carbohydrate fraction. It is also clear that the actual process conversion efficiencies that can be achieved will be critical to the economic success of the fuel production schemes. 


\section{SECTION 6.0}

\section{REFERENCES}

1. Benemann, J.R., B.L. Koopman, D.C. Baker, R.P. Goebe1, and W.J. Oswald, in "The Photosynthesis Energy Factory: Analysis, Synthesis, and Demonstration," Final Report for DOE Contract No. EX-76-C-01-2548: Intertechnology/Solar Corporation, 1978.

2. Milner, H.W., "The Chemical Composition of Algae," in J.S. Burlew, Algal Culture from Laboratory to Pilot Plant, Washington, DC: Carnegie Institution, 1976.

3. Tornabene, T.G., A. Ben-Amotz, S. Raziuddin, and J. Hubbard, "Chemical Profiles of Microalgae with Emphasis on Lipids," Final Report for SERI Subcontract No. XK-2-02149-1 (portions also published in "Screening for Lipid Yielding Microalgae," Final Subcontract Report SERI/STR-231-2207), Golden, CO: Solar Energy Research Institute, 1983.

4. Tornabene, T.G., "Chemical Profiles of Microalgae with Emphasis on Lipids," in Aquatic Species Program Review, Proceedings of the April 1984 Principa1 Investigators Meeting, SERI/CP-231-2341, Golden, CO: Solar Energy Research Institute, 1984.

5. Ben-Amotz, A., "Development of Outdoor Raceway Capable of Yielding Oilrich Halotolerant Microalgae. Identification of Oil-rich Strains," in Aquatic Species Program Review, Proceedings of the Apr11 1984 Principal Investigators Meeting, SERI/CP-231-2341, Golden, CO: Solar Energy Research Institute, 1984.

6. Hill, A.M., and D.A. Feinberg, "Fuel From Microalgae Lipid Products," SERI/TR-231-2348, Golden, CO: Solar Energy Research Institute, 1984.

7. Tornabene, T.G., personal communication, 1984.

8. Tahir, A.B., H.M. Lapp, and L.C. Buchanan, "Sunflower Oil as a Fuel for Compression Ignition Engines," in Proceedings of the International Conference on Plant and Vegetable $0 i 1 s$ as Fuels, American Society of Agricultural Engineers, 1982, p. 82.

9. Cowley, I.D., and D.A.J. Wase, "Anaerobic Digestion of Farm Wastes; a Review (part 1)," Process Biochemistry, August/September 1981, pp. 28-33.

10. Werner, D., "Productivity Studies on Diatom Cultures," Helgolander wiss Meersunters, Vol. 20, 1970 , p. 97. 


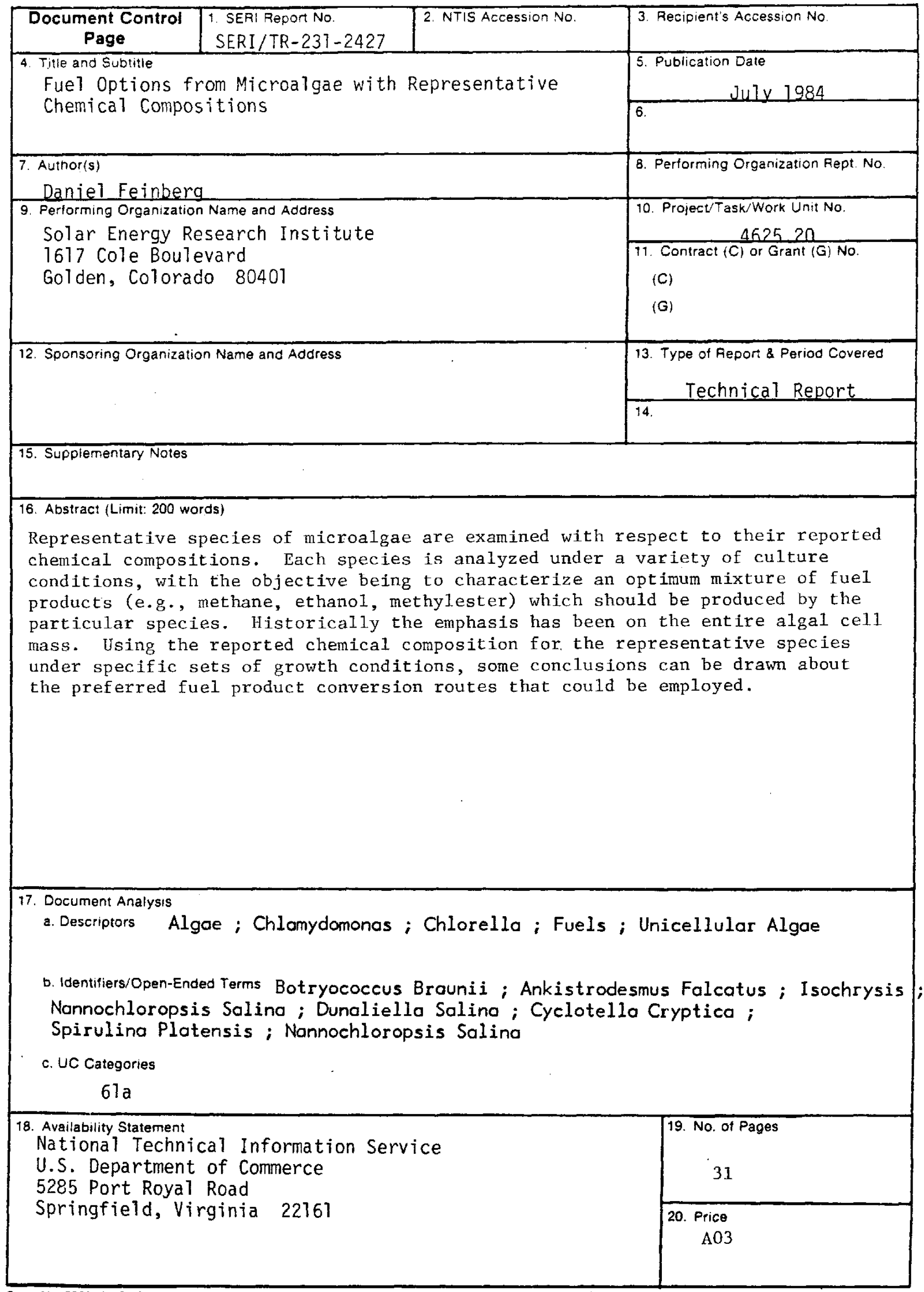

